\title{
KARAKTERISTIK PAPAN PARTIKEL DARI BAMBU DENGAN PEREKAT GETAH DAMAR
}

\section{CHARACTERISTIC OF PARTICLE BOARD FROM BAMBOO WITH DAMAR RESIN AS ADHESIVE}

\author{
Ika Amalia Kartika*) dan Dara Fegy Pratiwi \\ Departemen Teknologi Industri Pertanian, Fakultas Teknologi Pertanian, IPB \\ Kampus IPB Darmaga P.O. Box 220, Bogor 16002 \\ E-mail: ikatk@yahoo.com \\ Makalah: Diterima 21 Juni 2017; Diperbaiki 30 April 2018; Disetujui 12 Mei 2018
}

\begin{abstract}
The fiber content of bamboo is very high (59.8\%), thus it is potential to be the raw material for particle board manufacture. In this study, resin of damar was used as adhesive to substitute the synthetic adhesive such as urea and phenol formaldehide. The objective of this study were to characterize the particle board produced from bamboo with adhesive of damar resin, and to investigate the effect of pressing time and amount of resin added on physical and mechanical properties. This research was conducted on pressing temperatures of 130 and $150^{\circ} \mathrm{C}$ using randomized block design with two factors, i.e. pressing time (10 and $\left.14 \mathrm{~min}\right)$ and amount of resin added $(12,14,16 \%)$. The result of variance analysis showed that pressing time affected water adsorption of particleboard, while amount of resin added affected its thickness swelling. Both factors did not have the effect on density, moisture content, modulus of elasticity and rupture, and internal bonding of particleboard. Process condition of $14 \%$ resin added, 10 min pressing time and $150^{\circ} \mathrm{C}$ pressing temperature produced the particleboard with best characteristics, i.e. density of $0.55 \mathrm{~g} / \mathrm{cm}^{3}$, moisture content of $9.99 \%$, water adsorption of $72.6 \%$ at 2 hand $83.5 \%$ at 24 h, thickness swelling of $10.5 \%$ at 2 hand $18.0 \%$ at $24 \mathrm{~h}$, MOE of $393.5 \mathrm{kgf} / \mathrm{cm}^{2}$, MOR of 51.7 $\mathrm{kgf} / \mathrm{cm}^{2}$ and IB 0.90 of $\mathrm{kgf} / \mathrm{cm}^{2}$. These characteristics did not meet the standard of JIS A 5908-2003 and SNI 032105-2006.
\end{abstract}

Keywords: adhesive, bamboo, damar, resin, particle board

\section{ABSTRAK}

Bambu memiliki kadar serat kasar yang tinggi (59,8\%), sehingga potensial untuk dimanfaatkan sebagai bahan baku papan partikel. Pada penelitian ini getah damar digunakan sebagai perekat papan partikel. Getah damar dikembangkan untuk mensubstitusi perekat sintesis seperti urea dan fenol formaldehida. Tujuan dari penelitian ini adalah untuk mengkarakterisasi papan partikel yang diproduksi dari bambu dengan perekat getah damar, dan menganalisis pengaruh waktu kempa dan jumlah damar yang ditambahkan terhadap sifat fisik dan mekanik. Penelitian ini dilakukan pada suhu kempa 130 dan $150^{\circ} \mathrm{C}$, dan menggunakan rancangan acak kelompok dengan 2 faktor, yaitu waktu kempa (10 dan 14 menit) dan jumlah damar yang ditambahkan (12, 14 dan 16\%). Hasil analisis ragam menunjukkan bahwa waktu kempa mempengaruhi daya serap air papan partikel, sedangkan jumlah damar yang ditambahkan mempengaruhi pengembangan tebalnya. Kedua faktor tersebut tidak mempengaruhi kerapatan, kadar air, kekuatan lentur, keteguhan patah dan kuat rekat internal papan partikel. Karakteristik papan partikel terbaik dihasilkan pada suhu kempa $150^{\circ} \mathrm{C}$ dengan waktu kempa 10 menit dan jumlah damar yang ditambahkan $14 \%$. Pada kondisi proses tersebut papan partikel yang dihasilkan mempunyai kerapatan $0,546 \mathrm{~g} / \mathrm{cm}^{3}$, kadar air 9,99\%, daya serap air $72,6 \%$ (2 jam) dan $83,5 \%$ (24 jam), pengembangan tebal 10,5\% (2 jam) dan 18,0\% (24 jam), MOE 393,5 kgf/ $/ \mathrm{cm}^{2}$, MOR 51,7 kgf $/ \mathrm{cm}^{2}$ dan IB 0,90 kgf $/ \mathrm{cm}^{2}$. Karakteristik papan partikel tersebut belum memenuhi standar JIS A 5908-2003 dan SNI 03-2105-2006.

Kata kunci: bambu, damar, getah, papan partikel, perekat

\section{PENDAHULUAN}

Permintaan papan partikel dari tahun ke tahun terus meningkat seiring dengan peningkatan penggunaan papan partikel di berbagai sektor terutama sektor perumahan, bangunan dan furniture. Pada tahun 2010, Indonesia mengimpor 213.442 ton papan partikel, dan volume impor komoditas tersebut meningkat $163 \%$ pada tahun 2011. Papan partikel pada umumnya diproduksi dari partikel kayu atau bahan berlignoselulosa lainnya seperti jerami yang diikat dengan perekat organik atau sintetis (Maloney, 1993). Saat ini bahan baku untuk memproduksi papan partikel tidak sebatas dari kayu ataupun limbah kayu seiring dengan semakin terbatas dan tingginya harga kayu. Pemanfaatan bahan berlignoselulosa lainnya, seperti kenaf (Okuda dan Sato, 2004; Okuda et al., 2006), tandan kosong kelapa sawit (Hashim et al., 2010; Hashim et al., 2011a,b; Baskaran et al., 2012), bambu (Muin et al., 2006; Suranta, 2009) dan lain-lain, telah banyak dikembangkan.

Bambu merupakan bahan berlignoselulosa yang sangat potensial digunakan sebagai bahan baku untuk pembuatan papan partikel. Hal itu karena bambu memiliki kesesuaian sebagai bahan baku 
papan partikel ditinjau dari segi anatomis dan komposisi kimianya dimana batang bambu mengandung 52,9\% selulosa dan panjang serat 3-4 mm (Suranta, 2009). Selain itu, bambu memiliki pertumbuhan yang sangat cepat, umur panen yang pendek ( 3-5 tahun) dan mudah dibudidayakan (Muin et al., 2006). Perkiraan luas wilayah potensi bambu di Indonesia sebesar 170.393 ha, dengan potensi produksi sekitar 5,4 juta $\mathrm{m}^{3}$ (apabila per pohon/batang mempunyai volume $\left.0,25 \mathrm{~m}^{3}\right)$ (Pramono, 2012).

Industri papan partikel umumnya menggunakan urea formaldehida (UF) atau fenol formaldehida (FF) sebagai perekat dengan kadar sekitar 10-20\% (Tsoumis, 1991). Urea formaldehida (UF) dan fenol formaldehida (FF) merupakan resin yang disintesis dengan mereaksikan urea atau fenol dengan formaldehida (Achmadi, 1990). Isu pencemaran lingkungan dan gangguan kesehatan yang diakibatkan oleh emisi formaldehida telah mendorong penggunaan bahan organik sebagai perekat dalam pembuatan papan partikel. Beberapa penelitian menunjukkan bahwa protein dari berbagai jenis tanaman sangat potensial dimanfaatkan sebagai perekat papan partikel, seperti protein biji pea (Gueguen et al., 1998), protein biji bunga matahari (Evon et al., 2014a, 2015), protein kedelai (Li et al., 2009; Ciannamea et al., 2010), protein gandum (Cho et al., 2011), protein biji jarak pagar (Lestari dan Kartika, 2012; Diebel et al., 2012; Kartika et al., 2013; Evon et al., 2014b; Hidayat et al., 2014), protein biji jarak kepyar (Kurniati et al., 2014, 2015), getah damar (Sudarsono et al., 2010) dan lain-lain. Dibandingkan protein, penggunaan getah damar sebagai perekat dapat menghasilkan papan partikel dengan sifat fisik dan mekanik yang lebih baik. Hal ini dikarenakan getah damar mengandung resin alami yang tinggi dimana pada suhu tinggi resin damar akan mudah meleleh dan menyebar di antara pori-pori partikel, sehingga dapat meningkatkan sifat fisik dan mekanik papan partikel tersebut (Sudarsono et al., 2010). Getah damar dengan demikian sangat potensial digunakan sebagai alternatif perekat yang ramah lingkungan dalam pembuatan papan partikel.

Berdasarkan hal tersebut di atas, dalam penelitian ini dikaji pembuatan papan partikel dari bambu dengan perekat getah damar. Tujuan dari penelitian ini adalah untuk mengkarakterisasi papan partikel yang diproduksi dari bambu dengan perekat getah damar dan dikempa pada suhu 130 dan $150^{\circ} \mathrm{C}$, serta untuk menganalisis pengaruh waktu kempa dan jumlah damar yang ditambahkan terhadap sifat fisik dan mekanik.

\section{METODE PENELITIAN}

\section{Bahan dan Alat}

Bahan baku yang digunakan dalam penelitian ini adalah bambu tali (Gigantochloa apus) yang diperoleh dari pedagang bambu di daerah
Ciampea, serta getah damar yang diperoleh dari Hutan Pendidikan Gunung Walad Fakultas Kehutanan IPB. Peralatan yang digunakan adalah hammer mill, bak pencampur partikel dan perekat, blender, pencetak papan, plat aluminium, pengempa panas, ember plastik (wadah), oven, disk flaker, desikator, alat pemotong, jangka sorong, kaliper, timbangan elektrik, Universal Testing Machine (Instron 3369), dan peralatan lainnya untuk analisis. Pelarut dan bahan kimia yang digunakan adalah teknis dan analytical grade, yang diperoleh dari Sigma-Aldrich dan Brataco, Indonesia.

\section{Metode}

Karakterisasi Bambu

Bahan baku dengan kadar air $\pm 10 \%$ dipersiapkan dengan pengecilan ukuran batang bambu menjadi serbuk bambu berukuran 14 mesh dengan menggunakan hammer mill. Bahan baku kemudian dikarakterisasi dengan menganalisis kadar air (SNI 01 2891.1992), kadar minyak (SNI 01 2891.1992), kadar abu (SNI 01 2891.1992), kadar protein (SNI 01 2891.1992), kadar serat kasar (SNI 01 2891.1992) dan kadar karbohidrat (by difference) (SNI 01 2891.1992).

\section{Pembuatan Papan Partikel}

Getah damar dihancurkan hingga halus dengan menggunakan blender, dan sejumlah tertentu getah damar kemudian dicampur dengan serbuk bambu. Jumlah getah damar yang ditambahkan adalah sebesar 12, 14 dan $16 \%$ dari total berat bahan. Campuran serbuk bambu dan getah damar dimasukkan ke dalam cetakan berukuran $30 \mathrm{~cm}$ x 30 $\mathrm{cm} \times 1 \mathrm{~cm}$, dan hasil cetakan selanjutnya dikempa selama 10 dan 14 menit pada tekanan $20 \mathrm{kgf} / \mathrm{cm}^{2}$ dan suhu $130^{\circ} \mathrm{C}$ dan $150^{\circ} \mathrm{C}$. Kerapatan papan ditargetkan sebesar $0,7 \mathrm{~g} / \mathrm{cm}^{3}$.

Papan partikel yang dihasilkan dikondisikan pada suhu ruang selama 14 hari, dan selanjutnya dipotong pada ukuran tertentu sesuai dengan tujuan pengujian yang dilakukan. Ukuran contoh uji disesuaikan dengan standar pengujian JIS A 5908-2003 tentang papan partikel. Paramaterparameter fisik dan mekanik yang diuji meliputi kadar air, kerapatan, pengembangan tebal, daya serap air, keteguhan patah (modulus of rupture, MOR), kekuatan lentur (modulus of elasticity, MOE), dan keteguhan rekat internal (internal bond, IB).

\section{Rancangan Percobaan}

Penelitian ini dirancang dengan menggunakan rancangan acak kelompok, yang terdiri dari 2 faktor yang saling berinteraksi yaitu waktu kempa (A) [10 menit $\left(\mathrm{A}_{1}\right), 14$ menit $\left.\left(\mathrm{A}_{2}\right)\right]$ dan jumlah getah damar yang ditambahkan (B) [12\% $\left.\left(\mathrm{B}_{1}\right), \quad 14 \% \quad\left(\mathrm{~B}_{2}\right), \quad 16 \% \quad\left(\mathrm{~B}_{3}\right)\right]$. Pada rancangan percobaan ini terdapat 1 faktor pengganggu atau sampingan yang disebut kelompok dan tidak 
berinteraksi dengan faktor lain, yaitu suhu (K) $\left[130^{\circ} \mathrm{C}\left(\mathrm{K}_{1}\right), 150^{\circ} \mathrm{C}\left(\mathrm{K}_{2}\right)\right]$. Model matematik untuk Rancangan Acak Kelompok 2 faktor adalah sebagai berikut (Montgomery, 2001):

$$
Y_{i j m}=\mu+K_{m}+A_{i}+B_{j}+(A B)_{i j}+\varepsilon_{i j m}
$$

$\mathrm{Y}_{\mathrm{ijm}}$ adalah nilai pengamatan yang memperoleh kombinasi perlakuan ke-i (taraf perlakuan faktor A), ke-j (taraf perlakuan faktor B) dan kelompok ke-m, $\mu, A_{i}$ dan $B_{j}$ masing-masing merupakan nilai ratarata umum, pengaruh faktor waktu kempa pada taraf ke-i (i = 10 dan 14 menit), pengaruh faktor jumlah getah damar yang ditambahkan pada taraf ke-j $(\mathrm{j}=$ 12, 14 dan 16\%), (AB $)_{\mathrm{ij}}$ merupakan pengaruh interaksi antara faktor A taraf ke-i dan faktor B taraf ke-j, $\mathrm{K}_{\mathrm{m}}$ merupakan pengaruh kelompok ke-m ( $\mathrm{m}=$ $130^{\circ} \mathrm{C}$ dan $150^{\circ} \mathrm{C}$ ), sedangkan $\varepsilon_{\mathrm{ijm}}$ merupakan pengaruh galat atau error dari faktor A taraf ke-i, faktor B taraf ke-j dan kelompok ke-m.

Penelitian dilakukan dengan 2 kali ulangan, dan untuk setiap ulangan papan partikel diproduksi secara duplo. Untuk mengetahui pengaruh antar taraf faktor tersebut, data yang diperoleh dianalisis keragamannya menggunakan $\alpha=0,05$ dan dilanjutkan dengan uji lanjut Duncan.

\section{HASIL DAN PEMBAHASAN}

\section{Karakteristik Bambu}

Bambu tali yang digunakan dalam penelitian ini mempunyai kadar air $12,16 \%$, kadar minyak $0,01 \%$, kadar protein $0,72 \%$, kadar abu $1,99 \%$, kadar serat $59,75 \%$ dan kadar karbohidrat (by difference) 25,37\%. Dengan demikian, serat merupakan komponen utama bambu. Kandungan serat kasar yang tinggi ini memungkinkan bambu tali untuk dijadikan sebagai pengganti kayu dalam pembuatan papan partikel. Menurut Fatriasari dan Hermiati (2008), serat bambu tali terdiri dari 73,32\% holoselulosa (selulosa dan hemiselulosa) dan $32,66 \%$ lignin. Kandungan ketiga komponen tersebut yang berfungsi sebagai penguat dalam suatu bahan yang akan digunakan sebagai bahan baku untuk papan partikel akan mempengaruhi sifat fisik dan mekanik papan partikel yang dihasilkannya. Hal itu karena sifat higroskopis yang dimiliki oleh ketiga komponen tersebut. Banyaknya gugus hidroksil bebas pada molekul selulosa dan hemiselulosa mengakibatkan afinitasnya terhadap air dan potensinya untuk membentuk ikatan hidrogen tinggi, sehingga keduanya bersifat higroskopis (Achmadi, 1990). Sebaliknya lignin hanya memiliki sedikit gugus hidroksil bebas, sehingga lignin kurang bersifat higroskopis. Tingginya kandungan selulosa, hemiselulosa dan lignin dalam bambu tali ini kemungkinan akan menghasilkan papan partikel dengan daya serap air yang tinggi dan MOR yang relatif rendah.
Komponen lainnya yang terkandung dalam bambu tali adalah air, lemak, protein, abu dan karbohidrat. Komponen tersebut dapat digolongkan sebagai ekstraktif karena dapat larut dalam pelarut organik atau air. Menurut Maloney (1993), pada pembuatan papan partikel kandungan ekstraktif dalam suatu bahan berpengaruh pada konsumsi perekat dan laju pematangan, menghalangi pembasahan dan mengakibatkan terjadinya blowing pada saat pengempaan. Selain itu, tingginya kandungan ekstraktif pada bahan dapat menjadi penghalang penetrasi perekat dan menyebabkan penurunan sifat keterbasahan bahan (Iswanto, 2013). Ekstraktif dapat memblokir saluran noktah dalam sel, sehingga dapat mengurangi permeabilitas dan menghambat penetrasi perekat dalam struktur sel. Lebih lanjut, pada saat pengempaan panas ekstraktif akan bermigrasi ke permukaan substrat, sehingga keterbasahannya untuk bereaksi dengan perekat menjadi menurun. Dengan demikian, kandungan komponen selain serat dalam bambu tali juga akan mempengaruhi sifat fisik dan mekanik papan partikel yang dihasilkannya.

Pada penelitian ini papan partikel diproduksi dengan menggunakan perekat alami berupa getah damar. Penggunaan perekat alami ini adalah salah satu alternatif teknologi ramah lingkungan yang dapat dilakukan untuk meminimalkan kerusakan lingkungan. Getah damar memiliki titik lunak $144-149^{\circ} \mathrm{C}$ (Perhutani, 2014) dan titik leleh $90-130^{\circ} \mathrm{C}$. Pada titik lunak dan leleh tersebut getah damar mulai berubah wujud dari padat menjadi semi padat. Sifat-sifat papan partikel umumnya dipengaruhi oleh perekat yang digunakan, sehingga perekat adalah salah satu faktor penting yang menentukan, baik dilihat dari faktor teknis maupun ekonomis (Kusmayadi, 2001).

\section{Sifat Fisik dan Mekanik Papan Partike}

Hasil pengujian sifat fisik dan mekanik papan partikel bambu yang diproduksi dalam penelitian ini tercantum pada Tabel 1.

\section{Kerapatan}

Kerapatan papan partikel yang dihasilkan pada penelitian ini berkisar antara $0,5-0,6 \mathrm{~g} / \mathrm{cm}^{3}$ (Tabel 1). Kerapatan papan partikel tertinggi $(0,583$ $\mathrm{g} / \mathrm{cm}^{3}$ ) diperoleh dari perlakuan suhu kempa $150^{\circ} \mathrm{C}$ dengan waktu kempa 14 menit dan jumlah resin damar yang ditambahkan $16 \%$. Kerapatan papan partikel terendah $\left(0,532 \mathrm{~g} / \mathrm{cm}^{3}\right)$ diperoleh dari perlakuan suhu kempa $130^{\circ} \mathrm{C}$ dengan waktu kempa 14 menit dan jumlah resin damar yang ditambahkan $12 \%$. Seluruh papan partikel yang dihasilkan dari penelitian ini mempunyai kerapatan lebih rendah 
Tabel 1. Sifat fisik dan mekanik papan partikel dari bambu dengan perekat resin damar

\begin{tabular}{|c|c|c|c|c|c|c|c|c|c|c|c|}
\hline $\begin{array}{c}\text { Suhu } \\
\left({ }^{\circ} \mathbf{C}\right)\end{array}$ & $\begin{array}{l}\text { Waktu } \\
\text { (menit) }\end{array}$ & $\begin{array}{c}\text { Jumlah resin } \\
\text { damar }(\%)\end{array}$ & $\begin{array}{c}\text { Kerapatan } \\
\left(\mathrm{g} / \mathrm{cm}^{3}\right)\end{array}$ & $\underset{(\%)}{\text { Kadar air }}$ & $\begin{array}{c}\text { DSA } \\
(2 \mathrm{jam}, \%)\end{array}$ & $\begin{array}{c}\text { DSA } \\
(24 \text { jam, \%) }\end{array}$ & $\begin{array}{c}\text { PT } \\
(2 \text { jam, \%) }\end{array}$ & $\begin{array}{c}\text { PT } \\
(24 \text { jam, \%) }\end{array}$ & $\underset{\left(\mathbf{k g f} / \mathrm{cm}^{2}\right)}{\mathrm{MOE}}$ & $\underset{\left(\mathrm{kgf}^{\prime} / \mathrm{cm}^{2}\right)}{\mathrm{MOR}}$ & IB $\left(\mathrm{kgf} / \mathrm{cm}^{2}\right)$ \\
\hline 130 & 10 & 12 & $0,550 \pm 0,015$ & $10,5 \pm 0,0$ & $120,6 \pm 5,9$ & $130,3 \pm 10,8$ & $19,5 \pm 0,3$ & $26,1 \pm 1,7$ & $135,4 \pm 11,9$ & $19,1 \pm 1,7$ & $0,25 \pm 0,06$ \\
\hline 130 & 10 & 14 & $0,561 \pm 0,001$ & $10,0 \pm 0,1$ & $117,2 \pm 3,0$ & $122,2 \pm 3,3$ & $15,9 \pm 0,6$ & $24,1 \pm 2,7$ & $136,4 \pm 7,2$ & $19,5 \pm 1,4$ & $0,36 \pm 0,08$ \\
\hline 130 & 10 & 16 & $0,576 \pm 0,004$ & $9,7 \pm 0,1$ & $103,3 \pm 3,2$ & $108,1 \pm 2,9$ & $16,6 \pm 0,4$ & $21,4 \pm 0,1$ & $112,8 \pm 7,7$ & $15,0 \pm 0,3$ & $0,60 \pm 0,11$ \\
\hline 130 & 14 & 12 & $0,532 \pm 0,007$ & $10,4 \pm 0,0$ & $111,9 \pm 4,0$ & $126,0 \pm 5,8$ & $21,2 \pm 2,0$ & $30,1 \pm 2,2$ & $145,3 \pm 1,9$ & $23,6 \pm 2,9$ & $0,48 \pm 0,04$ \\
\hline 130 & 14 & 14 & $0,557 \pm 0,001$ & $9,5 \pm 0,2$ & $129,4 \pm 3,8$ & $145,8 \pm 5,5$ & $19,0 \pm 0,5$ & $26,9 \pm 0,4$ & $130,8 \pm 1,9$ & $20,2 \pm 1,3$ & $0,41 \pm 0,06$ \\
\hline 130 & 14 & 16 & $0,536 \pm 0,013$ & $10,4 \pm 0,3$ & $134,2 \pm 2,1$ & $144,0 \pm 4,7$ & $14,1 \pm 0,9$ & $16,1 \pm 2,4$ & $156,6 \pm 28,5$ & $24,3 \pm 3,8$ & $0,36 \pm 0,08$ \\
\hline 150 & 10 & 12 & $0,555 \pm 0,007$ & $9,9 \pm 0,1$ & $126,1 \pm 10,6$ & $138,8 \pm 13,4$ & $18,3 \pm 0,2$ & $28,3 \pm 1,4$ & $217,7 \pm 1,8$ & $26,7 \pm 1,8$ & $0,30 \pm 0,04$ \\
\hline 150 & 10 & 14 & $0,546 \pm 0,011$ & $10,0 \pm 0,1$ & $72,6 \pm 9,2$ & $83,5 \pm 10,7$ & $10,5 \pm 1,4$ & $18,0 \pm 2,4$ & $393,5 \pm 35,5$ & $51,7 \pm 5,0$ & $0,90 \pm 0,08$ \\
\hline 150 & 10 & 16 & $0,556 \pm 0,024$ & $10,2 \pm 0,1$ & $113,9 \pm 3,6$ & $126,8 \pm 8,4$ & $13,6 \pm 0,3$ & $22,0 \pm 1,6$ & $166,9 \pm 22,5$ & $21,4 \pm 4,0$ & $0,82 \pm 0,10$ \\
\hline 150 & 14 & 12 & $0,579 \pm 0,036$ & $9,7 \pm 0,1$ & $92,2 \pm 1,3$ & $109,9 \pm 1,9$ & $16,2 \pm 1,1$ & $27,5 \pm 2,4$ & $324,0 \pm 13,4$ & $38,8 \pm 4,0$ & $0,64 \pm 0,04$ \\
\hline 150 & 14 & 14 & $0,548 \pm 0,004$ & $10,1 \pm 0,0$ & $136,0 \pm 13,7$ & $149,7 \pm 6,1$ & $14,8 \pm 0,3$ & $24,7 \pm 1,9$ & $152,7 \pm 12,6$ & $17,8 \pm 2,7$ & $0,28 \pm 0,09$ \\
\hline 150 & 14 & 16 & $0,583 \pm 0,007$ & $9,5 \pm 0,1$ & $115,8 \pm 6,4$ & $128,6 \pm 6,8$ & $11,7 \pm 1,4$ & $21,4 \pm 1,9$ & $158,8 \pm 4,6$ & $21,1 \pm 4,0$ & $0,43 \pm 0,11$ \\
\hline
\end{tabular}


dari yang ditargetkan $\left(0,7 \mathrm{~g} / \mathrm{cm}^{3}\right)$, tetapi nilai kerapatannya tersebut telah memenuhi syarat JIS A 5908-2003 (0,40-0,90 g/ $\left.\mathrm{cm}^{3}\right)$.

Dibandingkan dengan papan partikel yang diproduksi dari bambu dengan perekat melamin formaldehida (Suhasman et al., 2010) dan dari sabut kelapa dengan perekat getah damar (Sudarsono et al., 2010), papan partikel yang dihasilkan dalam penelitian ini mempunyai kerapatan yang lebih rendah dan relatif sama $\left(0,5-0,6 \mathrm{~g} / \mathrm{cm}^{3}\right.$ vs $0,81 \mathrm{~g} / \mathrm{cm}^{3}$ untuk bambu dengan perekat melamin formaldehida vs $0,5-0,6 \mathrm{~g} / \mathrm{cm}^{3}$ untuk sabut kelapa dengan perekat getah damar). Rendahnya kerapatan papan yang dihasilkan dalam penelitian ini diduga akibat adanya kehilangan bahan (campuran partikel bambu dan resin damar) pada saat pencetakan papan sebelum dikempa, sehingga massa bahan menjadi berkurang. Selain itu, penyesuaian kadar air pada saat papan dikondisikan selama 14 hari menyebabkan ketebalan papan meningkat, sehingga nilainya melebihi target yang ditetapkan $(1 \mathrm{~cm})$. Kecenderungan tingginya penyerapan air pada saat pengkondisian papan disebabkan karena papan berkerapatan rendah memiliki rongga-rongga antar partikel yang lebih banyak. Hal tersebut meningkatkan penetrasi air ke dalam papan partikel. Semakin tebal suatu papan maka semakin rendah kerapatannya, demikian juga sebaliknya (Setyawati et al., 2008).

Hasil analisis keragaman menunjukkan bahwa jumlah getah damar yang ditambahkan dan waktu kempa tidak berpengaruh secara signifikan terhadap kerapatan papan partikel baik pada perlakuan suhu kempa $130^{\circ} \mathrm{C}$ maupun $150^{\circ} \mathrm{C}$. Berdasarkan hasil tersebut, kerapatan papan partikel yang dihasilkan pada penelitian ini tidak menunjukkan kecenderungan tertentu yang mengindikasikan adanya korelasi antara kerapatan papan dengan kombinasi perlakuan yang diberikan. Kerapatan papan partikel adalah konstan ketika jumlah getah damar yang ditambahkan dan waktu kempa ditingkatkan. Hal ini menunjukkan kemungkinan ada faktor lain, seperti perlakuan pendahuluan terhadap bahan, ukuran partikel bahan, tekanan kempa, dan sebagainya, yang pengaruhnya mungkin lebih signifikan terhadap kerapatan papan daripada ketiga faktor yang digunakan dalam penelitian ini.

Kerapatan merupakan suatu ukuran kekompakan partikel dalam suatu papan partikel, dan sangat tergantung pada kerapatan bahan yang digunakan dan tekanan yang diberikan selama pengempaan selain pada porositasnya, yaitu proporsi volume rongga kosong. Semakin tinggi kerapatan papan partikel maka akan semakin tinggi sifat keteguhannya. Bambu memiliki kerapatan 0,41-0,65 $\mathrm{g} / \mathrm{cm}^{3}$ (Syafi'i, 1984; Surjokusumo dan Nugroho, 1994; Pujirahayu, 2012). Kerapatan bahan baku yang tinggi dapat menyebabkan penurunan kekuatan papan, tetapi cenderung meningkatkan ketebalan papan (Kusmayadi, 2001). Hal tersebut karena semakin tinggi kerapatan bahan baku yang digunakan, semakin banyak kandungan zat pada dinding sel yang dapat menyebabkan masalah dalam pengerasan perekat dan menimbulkan blister akibat tekanan gas internal zat ekstraktif yang mudah menguap (Bowyer et al., 2003), sedangkan tekanan pengempaan yang diberikan pada saat pembuatan papan partikel akan meningkatkan ikatan antar partikel, sehingga papan partikel yang dihasilkan lebih tahan terhadap air dan lebih stabil (Iskandar dan Supriadi, 2011).

\section{Kadar Air}

Kadar air papan partikel yang dihasilkan pada penelitian ini kurang dari $13 \%$, yaitu berkisar antara 9,4-10,5\% (Tabel 1). Kadar air papan tertinggi $(10,5 \%)$ diperoleh dari perlakuan suhu kempa $130^{\circ} \mathrm{C}$ dengan waktu kempa 10 menit dan jumlah resin damar yang ditambahkan $12 \%$. Kadar air papan terendah $(9,5 \%)$ diperoleh dari perlakuan suhu kempa $150^{\circ} \mathrm{C}$ dengan waktu kempa 14 menit dan jumlah resin damar yang ditambahkan $16 \%$. Nilai ini tidak jauh berbeda dengan kadar air papan yang diproduksi dari bambu dengan perekat melamin formaldehida, yaitu sebesar 9,2\% (Suhasman et al., 2010). Kadar air papan dengan demikian telah memenuhi JIS A 5908-2003 dan SNI 03-2105-2006, yaitu pada kisaran 5-13\%. Kadar air menunjukkan kandungan air yang terdapat dalam papan partikel. Semakin tinggi kandungan air dalam suatu papan, maka papan semakin mudah rusak. Hal tersebut menunjukkan bahwa kualitas papan partikel semakin rendah bila kandungan air di dalamnya tinggi. Umumnya kadar air papan partikel lebih rendah dari kadar air bahan baku yang digunakan. Hal tersebut terjadi karena perlakuan panas yang diterima papan partikel pada saat pengempaan panas menyebabkan sebagian air yang terkandung dalam bahan teruapkan (Mardikanto et al., 2009). Ini dapat dibuktikan dari kadar air papan (9,4-10,5\%) yang dihasilkan dari penelitian ini nilainya lebih kecil dari kadar air bahan bakunya (12,16\%).

Hasil analisis keragaman menunjukkan bahwa jumlah getah damar yang ditambahkan dan waktu kempa tidak berpengaruh secara signifikan terhadap kadar air papan partikel baik pada perlakuan suhu kempa $130^{\circ} \mathrm{C}$ maupun $150^{\circ} \mathrm{C}$. Berdasarkan hasil tersebut, kadar air papan partikel yang dihasilkan pada penelitian ini tidak menunjukkan kecenderungan tertentu yang mengindikasikan adanya korelasi antara kadar air papan dengan kombinasi perlakuan yang diberikan. Kadar air papan partikel adalah konstan ketika jumlah getah damar yang ditambahkan dan waktu kempa ditingkatkan. Hal ini menunjukkan kemungkinan ada faktor lain yang pengaruhnya mungkin lebih signifikan terhadap kadar air papan daripada ketiga faktor yang digunakan dalam penelitian ini. 
Kadar air papan partikel sangat bergantung pada kondisi udara di sekelilingnya. Papan partikel terbuat dari bahan yang berlignoselulosa tinggi sehingga bersifat higroskopis, yang akan mengabsorbsi atau mendesorbsi uap air dari atau ke udara sekelilingnya. Kadar air papan partikel akan semakin rendah dengan semakin meningkatnya jumlah perekat yang ditambahkan. Ini banyak teramati pada papan partikel yang diproduksi dengan perekat urea dan fenol formaldehida (Hermawan et al., 2015). Hal tersebut dapat terjadi karena rongga antar partikel semakin rapat sehingga aksesibilitas uap air ke dalam papan partikel akan semakin sulit. Namun demikian pada penelitian ini kadar air papan partikel adalah konstan ketika jumlah getah damar yang ditambahkan ditingkatkan. Hal tersebut kemungkinan terjadi karena rongga antar partikel yang terbentuk pada jumlah getah damar ditambahkan tinggi ataupun rendah sama kerapatannya sehingga aksesibilitas uap air ke dalam papan partikel pun menjadi sama sulitnya baik pada kadar getah damar tinggi ataupun rendah.

Kadar air papan partikel menjadi faktor penting terutama dalam menjaga stabilitas dimensi papan. Fenomena yang umumnya terjadi adalah semakin tinggi kerapatan papan partikel, maka kadar air yang terkandung di dalamnya semakin rendah (Setiawan, 2008). Fenomena tersebut tidak teramati pada penelitian ini, karena baik kerapatan maupun kadar air, nilainya konstan dengan peningkatan jumlah getah damar yang ditambahkan dan waktu kempa. Pada jumlah getah damar yang ditambahkan dan waktu kempa tinggi ataupun rendah kemungkinan rongga antar partikel yang terbentuk sama kerapatannya sehingga aksesibilitas uap air ke dalam papan partikel pun rendah baik pada kadar getah damar dan waktu kempa tinggi ataupun rendah. Xu et al. (2004) menyatakan bahwa stabilitas dimensi papan partikel meningkat signifikan seiring meningkatnya kerapatan papan. Papan partikel yang memiliki kerapatan yang tinggi, partikelnya akan semakin kompak dan padat sehingga tidak banyak terdapat rongga atau pori di antara jalinan partikel yang dapat diisi oleh air (Kollmann et al., 1975).

\section{Daya Serap Air}

Hasil pengujian daya serap air papan partikel selama 2 dan 24 jam masing-masing berkisar antara $72-136 \%$ dan $83-150 \%$ (Tabel 1). Daya serap air papan tertinggi $(136,0 \%$ untuk 2 jam dan $149,7 \%$ untuk 24 jam) diperoleh dari perlakuan suhu kempa $150^{\circ} \mathrm{C}$ dengan waktu kempa 14 menit dan jumlah resin damar yang ditambahkan $14 \%$. Daya serap air papan terendah $(72,6 \%$ untuk 2 jam dan $83,5 \%$ untuk 24 jam) diperoleh dari perlakuan suhu kempa $150^{\circ} \mathrm{C}$ dengan waktu kempa 10 menit dan jumlah resin damar yang ditambahkan $14 \%$. Nilai ini sebanding dengan daya serap air papan (24 jam) yang diproduksi dari bambu dengan perekat melamin formaldehida, yaitu sebesar 84,7\% (Suhasman et al., 2010). Namun demikian nilai ini lebih tinggi dibandingkan dengan daya serap air papan partikel komersial berbasis kayu dan perekat resin formaldehida (65\%) (Hidayat et al., 2014), dan juga papan yang diproduksi dari bambu dengan perekat asam sitrat (<30\%) (Widyorini et al., 2015). Parameter daya serap air tidak ditentukan nilai standarnya baik pada JIS A 5908-2003 maupun SNI 03-2105-2006. Namun demikian papan partikel yang bermutu baik adalah papan partikel yang memiliki daya serap air yang rendah karena besarnya jumlah air yang diserap dapat mengurangi kekuatan papan partikel saat digunakan. Pengujian ini penting dilakukan untuk mengetahui ketahanan papan terhadap air terutama jika penggunaannya untuk keperluan eksterior dimana papan mengalami kontak langsung dengan udara luar (Lestari dan Kartika, 2012).

Hasil analisis keragaman terhadap daya serap air papan dengan waktu perendaman 2 jam (DSA 2 jam) menunjukkan bahwa interaksi antara waktu kempa dan jumlah getah damar yang ditambahkan berpengaruh secara signifikan terhadap DSA 2 jam. Hasil uji lanjut Duncan menunjukkan DSA 2 jam papan dengan perlakuan waktu kempa 14 menit dan jumlah getah damar yang ditambahkan $14 \%$ berbeda nyata dan lebih tinggi nilainya dibandingkan dengan perlakuan waktu kempa 10 menit dan jumlah getah damar yang ditambahkan 12 , 14 dan $16 \%$, serta waktu kempa 14 menit dan jumlah getah damar yang ditambahkan 12 dan $16 \%$. Tingginya daya serap air dengan waktu pengempaan yang lebih lama ini diduga karena rusaknya jaringan ikatan perekat. Kerusakan jaringan ikatan perekat ini menyebabkan air lebih mudah terserap ke dalam papan partikel (Syamani et al., 2008). Menurut Mulyono dan Apriyantono (2004), komponen utama getah damar adalah resin yang mengandung fraksi yang bersifat asam dan netral, seperti asam damarolat, asam ursonat, asam damarenolat, asam damarenoat, asam oleanolat, damaran, shoreaphenol, dan senyawa terpenoid (damadienon, damadienol, hidroksi damarenon, hidroksi hopanon), yang menyebabkan getah damar bersifat mudah melekat tetapi tidak tahan terhadap panas. Oleh karena itu pada waktu pengempaan panas yang lebih lama kemungkinan daya melekat getah damar menurun karena rusaknya jaringan ikatan perekat oleh panas.

Daya serap air papan partikel semakin meningkat seiring dengan bertambahnya waktu perendaman. Hal ini mempertegas bahwa waktu pengempaan panas yang lebih lama menyebabkan daya melekat getah damar menurun karena rusaknya jaringan ikatan perekat oleh sehingga daya serap air papan menjadi lebih tinggi dengan semakin bertambahnya waktu perendaman. Hasil analisis keragaman daya serap air papan dengan waktu perendaman 24 jam (DSA 24 jam) menunjukkan waktu kempa dan interaksi antara waktu kempa dan 
jumlah getah damar yang ditambahkan berpengaruh secara signifikan terhadap DSA 24 jam.

Hasil uji lanjut Duncan menunjukkan bahwa DSA 24 jam papan yang dikempa selama 14 menit berbeda nyata dan nilainya lebih tinggi dari papan yang dikempa selama 10 menit. Sama halnya dengan DSA 2 jam, DSA 24 jam papan dengan perlakuan waktu kempa 14 menit dan jumlah getah damar yang ditambahkan $14 \%$ berbeda nyata dan lebih tinggi nilainya dibandingkan dengan perlakuan waktu kempa 10 menit dan jumlah getah damar yang ditambahkan 12, 14 dan 16\%, serta waktu kempa 14 menit dan jumlah getah damar yang ditambahkan 12 dan $16 \%$.

\section{Pengembangan Tebal}

Hasil pengujian pengembangan tebal papan partikel selama 2 dan 24 jam masing-masing berkisar antara $10-22 \%$ dan $16-31 \%$ (Tabel 1). Pengembangan tebal papan tertinggi $(21,2 \%$ untuk 2 jam dan 30,1\% untuk 24 jam) diperoleh dari perlakuan suhu kempa $130^{\circ} \mathrm{C}$ dengan waktu kempa 14 menit dan jumlah resin damar yang ditambahkan $12 \%$. Pengembangan tebal papan terendah $(10,5 \%$ untuk 2 jam dan $16,1 \%$ untuk 24 jam) diperoleh masing-masing dari perlakuan suhu kempa $150^{\circ} \mathrm{C}$ dengan waktu kempa 10 menit dan jumlah resin damar yang ditambahkan $14 \%$, dan suhu kempa $130^{\circ} \mathrm{C}$ dengan waktu kempa 14 menit dan jumlah resin damar yang ditambahkan $16 \%$. Nilai ini lebih rendah dibandingkan dengan pengembangan tebal papan (24 jam) yang diproduksi dari bambu dengan perekat melamin formaldehida, yaitu sebesar 23,0\% (Suhasman et al., 2010). Namun demikian nilai ini lebih tinggi dibandingkan dengan papan yang diproduksi dari bambu dengan perekat asam sitrat (< 10\%) (Widyorini et al., 2015). Standar JIS A 5908:2003 dan SNI 03-2105-2006 menetapkan pengembangan tebal papan partikel maksimal $12 \%$. Seluruh papan partikel yang dihasilkan pada penelitian ini mutunya belum memenuhi standar untuk pengembangan tebal.

Menurut Mardikanto et al. (2009), pengembangan papan partikel yang tinggi tidak dapat digunakan untuk keperluan eksterior karena stabilitas produk yang rendah dan sifat mekaniknya akan menurun secara drastis dalam jangka waktu yang singkat. Dengan demikian papan yang dihasilkan pada penelitian ini tidak cocok digunakan untuk keperluan eksterior karena pengembangan tebalnya yang masih tinggi.

Hasil analisis keragaman terhadap pengembangan tebal papan dengan waktu perendaman 2 jam (PT 2 jam) menunjukkan bahwa jumlah getah damar yang ditambahkan dan interaksi antara waktu kempa dan jumlah getah damar yang ditambahkan berpengaruh secara signifikan terhadap PT 2 jam. Hasil uji lanjut Duncan menunjukkan tidak terdapat perbedaan nyata antara perlakuan jumlah getah damar yang ditambahkan 14\% dan
$16 \%$, namun keduanya berbeda nyata dengan perlakuan jumlah getah damar sebesar $12 \%$. Semakin tinggi jumlah getah damar yang ditambahkan terhadap bahan maka jumlah perekat yang menutupi pori-pori bahan semakin tinggi. Hal ini berarti ikatan antar partikel terjalin lebih rapat dan kekompakan yang terbentuk lebih sempurna, sehingga papan partikel dengan jumlah perekat lebih tinggi akan lebih sulit dimasuki air (Kusmayadi, 2001). Selain itu semakin tinggi jumlah getah damar yang ditambahkan terhadap bahan maka jumlah resin yang mengadung fraksi asam juga semakin tinggi. Peningkatan jumlah fraksi asam ini memungkinkan gugus ester yang terbentuk antara gugus $\mathrm{OH}$ dari bambu dan gugus karboksil dari asam meningkat sehingga sifat hidrofilik bambu menjadi berkurang dan papan menjadi lebih stabil (Widyorini et al., 2015). Hasil uji lanjut Duncan terhadap interaksi antara waktu kempa dan jumlah getah damar yang ditambahkan menunjukkan PT 2 jam papan dengan perlakuan waktu kempa 10 menit dan jumlah getah damar yang ditambahkan $12 \%$ berbeda nyata dan lebih tinggi nilainya dibandingkan dengan perlakuan waktu kempa 10 menit dan jumlah getah damar yang ditambahkan $14 \%$, serta waktu kempa 14 menit dan jumlah getah damar yang ditambahkan $16 \%$. Pengembangan tebal papan dengan perlakuan waktu kempa 14 menit dan jumlah getah damar yang ditambahkan $16 \%$ memiliki nilai paling rendah (12,9\%). Hal ini kemungkinan disebabkan papan yang diproduksi dengan jumlah getah damar yang lebih tinggi menyebabkan rongga-rongga kosong antar partikel lebih sedikit, sehingga penetrasi air ke dalam papan rendah.

\section{Modulus of Elasticity (MOE)}

Hasil pengujian MOE papan berkisar antara 112-394 kgf/ $\mathrm{cm}^{2}$ (Tabel 1). Papan akan semakin elastis apabila nilai kekuatan lenturnya semakin tinggi. Papan partikel yang dihasilkan dari perlakuan suhu kempa $150^{\circ} \mathrm{C}$, waktu kempa 10 menit dan jumlah getah damar yang ditambahkan $14 \%$ memiliki MOE paling tinggi, yaitu $393,5 \mathrm{kgf} / \mathrm{cm}^{2}$. Namun demikian nilai MOE ini masih jauh lebih rendah daripada yang dipersyaratkan JIS A 59082003 dan SNI 03-2105-2006 (minimal 20.000 $\mathrm{kgf} / \mathrm{cm}^{2}$ ). Nilai ini juga lebih rendah dibandingkan dengan MOE papan yang diproduksi dari bambu dengan perekat melamin formaldehida (16.243 $\mathrm{kgf} / \mathrm{cm}^{2}$ ) (Suhasman et al., 2010) dan perekat asam sitrat (> $20.000 \mathrm{kgf} / \mathrm{cm}^{2}$ ) (Widyorini et al., 2015).

Menurut Maloney (1993), kekuatan lentur papan partikel dipengaruhi oleh kandungan dan jenis bahan perekat yang digunakan, selain daya ikat rekat dan panjang serat bahan. Sifat lentur papan partikel yang dihasilkan dari penelitian ini kemungkinan karena kandungan $\alpha$-resin dan $\beta$-resin dalam perekat getah damar (Mulyono dan Apriyantono, 2004). $\beta$ resin merupakan senyawa polimer yang mempunyai berat molekul rendah, sedangkan $\alpha$-resin merupakan 
senyawa terpen yang terdiri dari damadienon, damadienol, hidroksi damarenon dan hidroksi hopanon. Selain itu juga karena adanya fraksi resin yang bersifat asam, seperti asam damarolat, asam ursonat, asam damarenolat dan asam damarenoat.

Hasil analisis keragaman menunjukkan MOE papan partikel yang dihasilkan dari perlakuan kelompok suhu kempa $150^{\circ} \mathrm{C}$ nilainya lebih tinggi dari perlakuan kelompok suhu kempa $130^{\circ} \mathrm{C}$. Hal ini selaras dengan hasil penelitian Widyorini et al. (2015) dimana MOE papan partikel bambu dengan perekat asam sitrat meningkat dengan peningkatan suhu kempa. Interaksi antara waktu kempa dan jumlah getah damar yang ditambahkan berpengaruh secara signifikan terhadap MOE papan. Hasil uji lanjut Duncan menunjukkan MOE papan dengan perlakuan waktu kempa 10 menit dan jumlah getah damar yang ditambahkan $14 \%$ berbeda nyata dan lebih tinggi nilainya dibandingkan dengan perlakuan waktu kempa 10 menit dan jumlah getah damar yang ditambahkan $16 \%$, serta waktu kempa 14 menit dan jumlah getah damar yang ditambahkan 14\%. Nilai MOE papan yang lebih tinggi pada waktu kempa yang lebih singkat dan kadar getah damar yang lebih rendah ini merupakan indikasi yang menguntungkan jika ditinjau dari aspek biaya produksinya.

Rendahnya nilai MOE papan partikel yang dihasilkan dari penelitian ini kemungkinan disebabkan karena ukuran partikel bambu yang digunakan pada penelitian ini lebih kecil dari 5 mesh, yaitu 14 mesh dimana hal tersebut akan memberikan efek negatif terhadap kekuatan papan partikel. Menurut Ruhendi et al. (2007), partikel dengan ukuran yang kecil sangat mudah mengikat perekat, sehingga apabila terkonsentrasi di bagian tertentu menyebabkan bagian lain kekurangan perekat. Selain itu juga dipengaruhi oleh suhu (130$\left.150^{\circ} \mathrm{C}\right)$ dan waktu kempa (10-14 menit) yang diterapkan pada saat pengempaan belum optimal sehingga pematangan perekat juga tidak optimal. Pada suhu rendah, kekuatan perekatan masih rendah karena perekat belum mengalami pematangan. Sedangkan pada suhu yang terlalu tinggi, perekat mengalami over curing sehingga mengurangi kekuatan ikatan pada garis ikatan. Tekanan kempa yang digunakan pada penelitian ini juga rendah (20 $\mathrm{kgf} / \mathrm{cm}^{2}$ ), lebih rendah dari besaran tekanan yang umumnya digunakan dalam pembuatan papan partikel $\left(25 \mathrm{kgf} / \mathrm{cm}^{2}\right)$.

\section{Modulus of Rupture (MOR)}

Keteguhan patah atau modulus of rupture (MOR) merupakan kekuatan lentur maksimum material hingga material tersebut patah (Mardikanto et al., 2009). Hasil pengujian MOR papan partikel berkisar antara 14-52 kgf/cm² (Tabel 1). Seperti halnya MOE, papan partikel yang dihasilkan dari perlakuan suhu kempa $150^{\circ} \mathrm{C}$, waktu kempa 10 menit dan jumlah getah damar yang ditambahkan $14 \%$ memiliki MOR paling tinggi, yaitu 51,7 $\mathrm{kgf} / \mathrm{cm}^{2}$. Namun demikian nilai MOR ini masih jauh lebih rendah daripada yang dipersyaratkan JIS A 5908-2003 dan SNI 03-2105-2006 (minimal 80 $\mathrm{kgf} / \mathrm{cm}^{2}$ ). Nilai ini juga jauh lebih rendah dibandingkan dengan MOR papan yang diproduksi dari bambu dengan perekat melamin formaldehida $\left(106,5 \mathrm{kgf} / \mathrm{cm}^{2}\right)$ (Suhasman et al., 2010) dan perekat asam sitrat (152,8 kgf/cm²) (Widyorini et al., 2015). Hasil analisis keragaman menunjukkan MOR papan partikel yang dihasilkan dari perlakuan kelompok suhu kempa $150^{\circ} \mathrm{C}$ nilainya lebih tinggi dari perlakuan kelompok suhu kempa $130^{\circ} \mathrm{C}$. Hal ini selaras dengan hasil penelitian Widyorini et al. (2015) dimana MOR papan partikel bambu dengan perekat asam sitrat meningkat dengan peningkatan suhu kempa. Interaksi antara waktu kempa dan jumlah getah damar yang ditambahkan berpengaruh secara signifikan terhadap MOR papan. Hasil uji lanjut Duncan menunjukkan MOR papan dengan perlakuan waktu kempa 10 menit dan jumlah getah damar yang ditambahkan $14 \%$ berbeda nyata dan lebih tinggi nilainya dibandingkan dengan perlakuan-perlakuan lainnya, kecuali perlakuan waktu kempa 14 menit dan jumlah getah damar yang ditambahkan $12 \%$.

\section{Internal Bonding}

Keteguhan rekat internal atau internal bound (IB) merupakan keteguhan tarik tegak lurus permukaan lembaran papan partikel. Nilai IB papan partikel menggambarkan kekuatan ikatan antar partikel, sehingga IB dapat digunakan sebagai parameter untuk menentukan kualitas lembaran dimana hal tersebut berkaitan dengan sistem pembuatan papan partikel yang diterapkan. Hasil pengujian IB papan partikel berkisar antara 0,2-0,9 $\mathrm{kgf} / \mathrm{cm}^{2}$ (Tabel 1). Seperti halnya MOE dan MOR, papan partikel yang dihasilkan dari perlakuan suhu kempa $150^{\circ} \mathrm{C}$, waktu kempa 10 menit dan jumlah getah damar yang ditambahkan $14 \%$ memiliki IB paling tinggi, yaitu $0,90 \mathrm{kgf} / \mathrm{cm}^{2}$. Apabila dibandingkan dengan JIS A 5908-2003 dan SNI 032105-2006 (minimal 1,5 kgf/cm²), IB papan partikel yang dihasilkan dari penelitian ini seluruhnya belum memenuhi standar. Nilai ini juga jauh lebih rendah dibandingkan dengan IB papan yang diproduksi dari bambu dengan perekat melamin formaldehida $(2,7$ $\mathrm{kgf} / \mathrm{cm}^{2}$ ) (Suhasman et al., 2010) dan perekat asam sitrat $\left(3,6 \mathrm{kgf} / \mathrm{cm}^{2}\right)$ (Widyorini et al., 2015).

Hasil analisis keragaman menunjukkan IB papan partikel yang dihasilkan dari perlakuan kelompok suhu kempa $150^{\circ} \mathrm{C}$ nilainya lebih tinggi dari perlakuan kelompok suhu kempa $130^{\circ} \mathrm{C}$. Ruhendy et al. (2007) menyatakan bahwa kekentalan perekat akan menentukan daya rekat dari perekat dengan bahan digunakan. Getah damar mempunyai kekentalan sekitar 4,03-26,25 cP (Mulyono dan Apriyantono, 2004), dan kekentalannya tersebut menurun seiring dengan peningkatan suhu. Kekentalan getah damar kemungkinan lebih rendah 
pada suhu kempa $150^{\circ} \mathrm{C}$ sehingga daya rekat dari perekat dengan bahan yang digunakan lebih baik pada suhu kempa tersebut. Interaksi antara waktu kempa dan jumlah getah damar yang ditambahkan berpengaruh secara signifikan terhadap IB papan. Hasil uji lanjut Duncan menunjukkan IB papan dengan waktu kempa 10 menit dan jumlah getah damar yang ditambahkan $16 \%$ tidak berbeda nyata dengan perlakuan-perlakuan lainnya, kecuali dengan perlakuan waktu kempa 10 menit dan jumlah getah damar yang ditambahkan $12 \%$. Secara umum peningkatan kadar perekat meningkatkan IB papan partikel yang dihasilkan. Hal ini berkaitan dengan peningkatan keterbasahan dari permukaan partikel oleh perekat dan peningkatan luas permukaan partikel. Menurut Maloney (1993), pada waktu proses pengempaan partikel akan mengalami kehancuran sehingga hal tersebut akan meningkatkan penyebaran perekat per satuan luas. Dengan semakin tinggi kadar perekat yang ditambahkan maka penyebaran perekat per satuan luas pun semakin besar, sehingga akan menghasilkan papan dengan IB yang baik. Bowyer et al. (2007) menyatakan bahwa keteguhan rekat akan semakin sempurna dengan bertambahnya jumlah perekat yang digunakan pada proses pembuatan papan partikel.

\section{KESIMPULAN DAN SARAN}

\section{Kesimpulan}

Karakteristik papan partikel dari bambu dengan perekat getah damar, terutama daya serap air dan pengembangan tebal, dipengaruhi oleh jumlah getah damar yang ditambahkan dan waktu kempa. Karakteristik papan partikel terbaik diperoleh dari perlakuan $14 \%$ jumlah getah damar yang ditambahkan dan waktu kempa 10 menit pada suhu pengempaan sebesar $150^{\circ} \mathrm{C}$. Pada kondisi proses tersebut papan partikel yang dihasilkan mempunyai kerapatan $0,546 \mathrm{~g} / \mathrm{cm}^{3}$, kadar air $9,99 \%$, daya serap air $72,6 \%$ (2 jam) dan $83,5 \%$ (24 jam), pengembangan tebal $10,5 \%$ (2 jam) dan $18,0 \%$ (24 jam), MOE 393,5 kgf/cm ${ }^{2}$, MOR 51,7 kgf/ $\mathrm{cm}^{2}$ dan IB $0,90 \mathrm{kgf} / \mathrm{cm}^{2}$. Sifat fisik dan mekanik papan partikel tersebut belum memenuhi standar JIS A 5908-2003 dan SNI 03-2105-2006.

\section{Saran}

Peningkatan kualitas papan partikel selanjutnya dapat dilakukan dengan meningkatkan suhu dan tekanan pengempaan sehingga karakteristik papan partikel dapat diperbaiki.

\section{DAFTAR PUSTAKA}

Achmadi SS. 1990. Kimia Kayu. Bogor: Institut Pertanian Bogor.

Baskaran M, Hashim R, Said N, Raffi SM, Balakrishnan K, Sudesh K, Sulaiman O, Arai
T, Kosugi A, Mori Y, Sugimoto T, Sato M. 2012. Properties of binderless particleboard from oil palm trunk with addition of polyhydroxyalkanoates. Composites: Part B. 43:1109-1116.

Bowyer JL, Shmulsky R, dan Haygreen JG. 2003. Forest Product and Wood Science. USA: Blackwell Publishing Professional.

Cho SW, Gällstedt M, Johansson E, Hedenqvist MS. 2011. Injection-molded nanocomposites and materials based on wheat gluten. International Journal of Biological Macromolecules. 48:146-152.

Ciannamea EM, Stefani PM, dan Ruseckaite RA. 2010. Medium-density particleboard from modified rice husk and soybean protein concentrate-based adhesives. Bioresource Technology. 101:818-825.

Diebel W, Reddy MM, Misra M, Mohanty A. 2012. Material property characterization of coproducts from biofuel industries: potential uses in value-added biocomposites. Biomass and Bioenergy. 37:88-96.

Evon P, Vandenbossche V, Pontalier PY, Rigal L. 2014a. New thermal insulation fiberboards from cake generated during biorefinery of sunflower whole plant in a twin-screw extruder. Industrial Crops and Products. 52:354-362.

Evon P, Kartika IA, dan Rigal L. 2014b. New renewable and biodegradable particleboards from jatropha press cakes. Journal of Renewable Materials. 2:52-65.

Evon P, Vinet J, Labonne L, Rigal L. 2015. Influence of thermo-pressing conditions on the mechanical properties of biodegradable fiberboards made from a deoiled sunflower cake. Industrial Crops and Products. 65:117126.

Fatriasari W dan Hermiati E. 2008. Analisis morfologi serat dan sifat fisis-kimia pada enam jenis bamboo sebagai bahan baku pulp dan kertas. JITHH. 1(2):67-72.

Gueguen J, Viroben G, Noireaux P, Subirade M. 1998. Influence of plasticizer and treatment on the properties of film from pea proteins. Industrial Crops and Products. 7:149-157.

Hashim R, Saari N, Sulaiman O, Sugimoto T, Hiziroglu S, Sato M, Tanaka R. 2010. Effect of particle geometry on the properties of binderless particleboard manufactured from oil palm trunk. Materials and Design. 31:4251-4257.

Hashim R, Nadhari WNAW, Sulaiman O, Kawamura F, Hiziroglu S, Sato M, Sugimoto T, Seng TG, Tanaka R. 2011a. Characterization of raw materials and manufactured binderless particleboard from oil palm biomass. Materials and Design. 32:246-254. 
Hashim R, Said N, Lamaming J, Baskaran M, Sulaiman O, Sato M, Hiziroglu S, Sugimoto T. 2011b. Influence of press temperature on the properties of binderless particleboard made from oil palm trunk. Materials and Design. 32: 2520-2525.

Hermawan D, Agustina A, Suparno O, Kartika IA. 2015. Sifat fisik dan mekanik papan partikel dari cangkang buah jarak pagar. Jurnal Teknologi Industri Pertanian. 25(3):279-292.

Hidayat H, Keijsers ERP, Prijanto U, van Dam JEG, Heeres HJ. 2014. Preparation and properties of binderless boards from Jatropha curcas L. seed cake. Industrial Crops and Products. 52:245-254.

Iskandar MI dan Supriadi A. 2011. Pengaruh besaran kempa terhadap sifat papan partikel serutan kayu. Penelitian Hasil Hutan. 29(3):226-233.

Iswanto AH. 2013. Optimasi faktor penentu kualitas dalam pembuatan papan partikel kulit buah jarak (Jatropha curcas L.). [Disertasi]. Bogor: Institut Pertanian Bogor.

Kartika IA, Fahma F, Yani M, Hermawan D. 2013. Sifat fisik dan mekanik papan partikel dari bungkil biji jarak pagar. Jurnal Teknologi Industri Pertanian. 23:109-119.

Kollmann FFP, Kuenzi EW, dan Stamm AJ. 1975. Principles of Wood Science and Technology. New York: Springer.

Kurniati M, Fahma F, Amalia Kartika I, Sunarti TC, Syamsu K, Hermawan D. 2014. Sifat fisik dan mekanik papan partikel dari bungkil jarak kepyar. Jurnal Teknologi Industri Pertanian. 24(2):125-136.

Kurniati M, Fahma F, Amalia Kartika I, Sunarti TC, Syamsu K, Hermawan D, Saito Y, Sato M. 2015. Binderless particleboard from castor seed cake: Effect of pressing temperature on physical and mechanical properties. Asian Journal of Agricultural Research. 9(4):180188.

Kusmayadi. 2001. Pengaruh rasio kompresi (compaction ratio) terhadap sifat fisis dan mekanis papan partikel beberapa jenis kayu. JITHH. 1(1):15-16.

Lestari S dan Kartika IA. 2012. Pembuatan papan partikel dari ampas biji jarak pagar pada berbagai kondisi proses. JAII. 1(1):11-17.

Li X, Li Y, Zhong Z, Wang D, Ratto JA, Sheng K, Sun XS. 2009. Mechanical and water soaking properties of medium density fiberboard with wood fiber and soybean protein adhesive. Bioresource Technology. 100:3556-3562.

Maloney TM. 1993. Modern Particleboard and DryProcess Fiberboard Manufacturing. San Fransisco: Miller Freeman, Inc.

Mardikanto TR, Karlinasari L, dan Bahtiar ET. 2009. Sifat Mekanis Kayu. Bogor: Institut Pertanian Bogor.
Montgomery DC. 2001. Design and Analysis of Experiments. USA: John Wiley \& Sons, Inc.

Muin M, Suhasman, Oka NP, Putranto B, Baharuddin, Millang S. 2006. Pengembangan Potensi dan Pemanfaatan Bambu sebagai Bahan Baku Konstruksi dan Industri di Sulawesi Selatan. Makasar: Badan Penelitian dan Pengembangan Daerah.

Mulyono N dan Apriyantono A. 2004. Sifat fisik, kimia dan fungsional damar. Jurnal Teknologi dan Industri Pangan. 15(3):245-252.

Okuda N dan Sato M. 2004. Manufacture and mechanical properties of binderless boards from kenaf core. Journal Wood Science.50:53-61.

Okuda N, Ori K, dan Sato M. 2006. Chemical changes of kenaf core binderless boards during hot pressing (II): Effect of the binderless board properties. Journal Wood Science. 52:249-254.

Perhutani. 2014. Kopal. http://www.bumn.go.id/ perhutani/halaman/156. [01 Juni 2015].

Pramono J. 2012. Kebijakan Sektor Hulu dan Peran Kemenhut dalam Pengembangan Bambu. Jakarta: Ditjen Kerjasama Industri Internasional.

Pujirahayu N. 2012. Kajian sifat fisik beberapa jenis bambu di Kecamatan Tonggauna Kabupaten Konawe. Agriplus. 22(3): 224-230.

Ruhendy S, Koroh DN, Syamani FA, Yanti H, Nurhaida, Saad S, Sucipto T. 2007. Analisis Perekatan Kayu. Bogor: Institut Pertanian Bogor.

Setiawan B. 2008. Papan partikel dari sekam padi. [Skripsi]. Bogor: Institut Pertanian Bogor.

Setyawati D, Sirait SM, dan Rahmaniah D. 2008. Sifat-sifat papan komposit dari sabut kelapa, limbah plastik dan perekat urea formaldehida. JITHH. 1(1):94-103.

Sudarsono, Rusianto T, dan Suryadi Y. 2010. Pembuatan papan partikel berbahan baku sabut kelapa dengan bahan pengikat alami (lem kopal). Jurnal Teknologi.3(1):22-32.

Suhasman, Massijaya MY, Hadi YS, Santoso A. 2010. Karakteristik papan partikel dari bambu tanpa menggunakan perekat. Jurnal Ilmu dan Teknologi Hasil Hutan. 3(1):38-43.

Suranta H. 2009. Oriented Strand Board dari Tiga Jenis Bambu. Medan: Universitas Sumatera Utara.

Surjokusumo S dan Nugroho N. 1994. Pemanfaatan Bambu sebagai Bahan Bangunan: Strategi Penelitian Bambu Indonesia. Bogor:Yayasan Bambu Lingkungan Lestari. P82-87.

Syafi'i LI. 1984. Pengujian sifat-sifat fisik dan mekanik contoh kecil bebas cacat beberapa jenis bambu. [Skripsi]. Bogor: Institut Pertanian Bogor. 
Syamani FA, Prasetiyo KW, Budiman I, Subyakto, Subiyanto B. 2008. Sifat fisis mekanis papan partikel dari serat sisal atau serat abaka setelah perlakuan uap. Jurnal Ilmu dan Teknologi Кауи Tropis. 6(2).

Tsoumis G. 1991. Science and Technology of Wood: Structure, Properties, Utilization. New York: Van Nostrand Reinhold.

Xu J, Sugawara R, Widyorini R, Han G, Kawai S. 2004. Manufacture and properties of lowdensity binderless particle board from kenaf core. Journal of Wood Science. 50:62-67.
Widyorini R, Yudha AP, Lukmandaru G, Prayitno TA. 2015. Sifat fisika mekanika dan ketahanan papan partikel bambu dengan perekat asam sitrat terhadap serangan rayap kayu kering. Jurnal Ilmu Kehutanan. 9(1):1222. 